\title{
Analisis Kestabilan Model Matematika Pada Penyebaran Penyalahgunaan Narkotika Dengan Memperhatikan Tipe Rehabilitasi
}

\author{
Tjang Daniel Chandra ${ }^{1, a)}$ dan Reza Umami Khoirunisa'1, b) \\ ${ }^{1} J u r u s a n$ Matematika, Fakultas MIPA, Universitas Negeri Malang, Malang Provinsi Jawa Timur \\ a)email: tjang.daniel.fmipa@um.ac.id (corresponding author) \\ b) email: reza.umami.1703126@students.um.ac.id
}

\begin{abstract}
Abstrak
Narkotika merupakan bagian dari napza. Napza adalah singkatan dari narkotika, psikotropika, dan zat adiktif lainnya. Napza diciptakan untuk kebutuhan medis dan pengobatan serta memiliki efek tersendiri, sehingga peredarannya sangat diatur oleh pemerintah. Penyalahgunaan narkotika sendiri akan berakibat buruk terhadap kesehatan karena mengakibatkan ketergantungan. Untuk mengatasi masalah tersebut, pemerintah melaksanakan program rehabilitasi sebagai upaya pencegahan peningkatan jumlah penyalahgunaan narkotika. Tujuan dari penelitian ini adalah menganalisa kestabilan model matematika pada penyebaran penyalahgunaan narkotika dengan memperhatikan tipe rehabilitasi dan mensimulasikan model berdasarkan data yang diperoleh dari buku Press Release Akhir Tahun 2020 Badan Narkotika Nasional. Model matematika tersebut membagi populasi atas lima kelompok individu. Dari hasil analisa, didapatkan dua titik kesetimbangan yaitu titik kesetimbangan bebas narkotika dan titik kesetimbangan adanya penyebaran narkotika. Jika nilai bilangan reproduksi dasar $\left(R_{0}\right)<1$ maka titik kesetimbangan bebas narkotika dikatakan stabil asimtotik lokal artinya jumlah populasi penyalahguna narkotika akan berkurang dan dalam jangka waktu tertentu akan menghilang, dan jika nilai $R_{0}>1$ maka titik ekuilibrium adanya penyebaran narkotika dikatakan stabil asimtotik lokal artinya jumlah populasi penyalahguna narkotika akan terus bertambah dan terjadi penyebaran penyalahgunaan narkotika. Pada penelitian ini, diperoleh bilangan reproduksi dasar $R_{0}=$ $0,1089756291<1$ mengartikan pada waktu yang lama akan menuju titik kesetimbangan dengan rata-rata penyalahgunaan narkotika sudah tidak menyebar.
\end{abstract}

Kata kunci: Narkotika, Rehabilitasi, Model Matematika, Bilangan Reproduksi Dasar

\begin{abstract}
Narcotics are part of drugs. Napza is an abbreviation of narcotics, psychotropics, and other addictive substances. Drugs are created for medical and medical needs and have their own effects, so their circulation is highly regulated by the government. Narcotics abuse itself will be bad for health because it causes dependence. To overcome this problem, the government implemented a rehabilitation program as an effort to prevent the increase in the number of narcotics abuse. The purpose of this study was to analyze the stability of the mathematical model on the spread of narcotics abuse by
\end{abstract}


paying attention to the type of rehabilitation and to simulate the model based on data obtained from the 2020 National Narcotics Agency's Final Press Release book. The mathematical model divides the population into five groups of individuals. From the results of the analysis, two equilibrium points were obtained, namely the narcotic-free equilibrium point and the equilibrium point for the distribution of narcotics. If the value of the basic reproduction number means the narcotic-free equilibrium point is said to be locally asymptotically stable, it means that the population of narcotics abusers will decrease and within a certain period of time it will disappear, and if the value means that the equilibrium point for the distribution of narcotics is said to be locally asymptotically stable, it means that the population of narcotics abusers will continue to grow. and the spread of drug abuse. In this study, the basic reproduction number was obtained which means that in a long time it will reach the equilibrium point with the average narcotic abuse not spreading.

Keywords: Narcotics, Rehabilitation, Mathematical Models, Basic Reproduction Numbers

\section{Pendahuluan}

Narkotika merupakan bagian dari napza. Napza adalah singkatan dari narkotika, psikotropika dan zat adiktif lainnya, yang mana sebenarnya mengandung bahan-bahan berbahaya, namun diciptakan untuk kebutuhan medis dan pengobatan serta memiliki efek tersendiri, sehingga peredarannya sangat diatur oleh pemerintah [1]. Narkotika sendiri merupakan obat atau zat yang berasal dari tanaman atau bukan tanaman, sintetis atau semi sintetis yang mana dapat menimbulkan ketergantungan, menurunkan kesadaran, serta dapat menghilangkan rasa nyeri [2]. Adapun macam-macam narkotika seperti ganja, morfin, kokain, heroin, codein [3].

Saat ini narkotika telah banyak disalahgunakan dengan pemakaian di luar dosis yang disarankan [4]. Penyalahgunaan narkotika berakibat buruk terhadap kesehatan karena dapat mengakibatkan ketergantungan. Bahaya ketergantungan ini dapat menyebabkan gangguan kesehatan, baik mental, fisik, maupun sosial yang menimbulkan kerusakan organ tubuh, gangguan daya berpikir, serta perilaku [5]. Untuk mengatasi masalah tersebut, pemerintah melaksanakan program pencegahan peningkatan jumlah penyalahgunaan narkotika, yaitu program rehabilitasi. Melalui program rehabilitasi, pemerintah berharap masyarakat yang sudah menjadi penyalahguna narkotika tidak lagi mengkonsumsi napza [6]. Program rehabilitasi merupakan suatu proses perawatan atau pengobatan untuk memberhentikan para pecandu dari ketergantungan narkotika dan masa menjalani perawatan atau rehabilitasi dapat diperhitungkan sebagai hukuman [7].

Pemodelan matematika merupakan salah satu alat atau sarana yang dapat digunakan untuk mempelajari dinamika penyebaran penyalahgunaan narkotika. Model matematika dapat digunakan sebagai representasi dari sistem-sistem fisik atau masalah dunia nyata dalam pernyataan matematika [8],[9],[10]. Telah banyak matematikawan yang mengembangkan model matematika untuk mempelajari penyebaran penyalahgunaan napza. Pemodelan matematika pada penyebaran penyalahgunaan napza pertama kali dipelajari oleh White dan Comiskey [11], dimana dalam penelitian tersebut kelas populasi manusia dibagi menjadi tiga kelas subpopulasi yakni populasi individu rentan menjadi penyalahguna napza, populasi individu penyalahguna napza yang tidak menjalani perawatan, dan populasi individu penyalahguna napza dalam masa perawatan. Model tersebut kemudian disebut model White-Comiskey [12].

Mushanyu dan Nyabadza dalam [13] mengkonstruksikan model SUTR (Susceptible-UsersTreatment-Recovered) guna mempelajari dinamika penyalahgunaan napza, dimana populasi susceptible dan recovered berturut-turut terdiri dari tingkat resiko menyalahgunakan narkoba yaitu 
resiko tinggi dan rendah. Sedangkan [14] memformulasikan dinamika model transmisi obat sintesis dengan ketergantungan psikologis dan tingkat kejadian umum. Selanjutnya [15] telah menganalisis dan mengkonstruksi model matematika penyalahgunaan napza dengan faktor kapasitas rehabilitasi yang terbatas. Hasil analisis menunjukkan bahwa peningkatan akses ke rehabilitasi cenderung menurunkan epidemi penyalahgunaan narkoba. Sedang pada penelitian [16] mempelajari model matematika dinamika jumlah pengguna narkoba untuk melihat bagaimana dampak hukuman mati yang telah diberlakukan di Indonesia terhadap pengguna narkoba.

Penulisan penelitian ini merujuk pada artikel yang ditulis oleh [17] yang berjudul Role of Imitation and Limited Rehabilitation Capacity on the Spread of Drug Abuse. Berdasarkan artikel tersebut, model tidak menyertakan kompartemen Recovered atau individu yang pulih dari penyalahgunaan napza. Sehingga pada penelitian ini akan dilakukan analisis kestabilan dengan modifikasi pada kompartemen Recovered dalam kasus penyalahgunaan narkotika di Indonesia. Pada penelitian ini, model yang digunakan akan mempertimbangkan adanya tipe rehabilitasi yang dijalani oleh penyalahguna narkotika, yaitu rehabilitasi rawat jalan dan rawat inap.

\section{Metode}

Penelitian ini menggunakan data sekunder yang didapatkan dari buku Press Release Akhir Tahun 2020 oleh Badan Narkotika Nasional, serta beberapa literatur berupa jurnal internasional, artikel, dan buku teks yang terkait dengan model epidemi. Adapun langkah-langkah yang dilakukan dalam penelitian ini yaitu: 1 . Membuat asumsi dan formulasi model matematika penyalahgunaan narkotika, 2. Mengumpulkan data kuantitatif dan estimasi parameter, 3. Mencari titik ekuilibrium model matematika penyalahgunaan narkotika, 4. Menentukan bilangan reproduksi dasar, 4. Analisis kestabilan titik ekuilibrium dari model matematika penyalahgunaan narkotika, 5. Simulasi numerik analisis kestabilan dengan Maple 20.

\section{Hasil dan Diskusi}

Pada model ini, populasi manusia dibagi menjadi lima kelompok individu yaitu kelompok individu rentan untuk menyalahgunakan narkotika $(S)$, kelompok individu penyalahguna narkotika $(U)$, kelompok individu penyalahguna narkotika yang mendapat rehabilitasi rawat jalan $\left(T_{o p}\right)$, kelompok individu penyalahguna narkotika yang mendapat rehabilitasi rawat inap $\left(T_{i p}\right)$, dan kelompok individu yang pulih dari penyalahgunaan narkotika $(R)$.

Terdapat beberapa asumsi yang akan digunakan dalam model matematika penyebaran penyalahgunaan narkotika dengan memperhatikan tipe rehabilitasi:

1. Penyalahguna narkotika yang telah pulih dapat menyalahgunakan narkotika kembali.

2. Penyalahguna yang tidak mendapatkan rehabilitasi dapat menyebarkan narkotika.

3. Penyalahguna narkotika yang menjalani rehabilitasi rawat jalan dapat menyalahgunakan narkotika kembali saat berinteraksi dengan penyalahguna yang tidak menjalani rehabilitasi.

4. Penyalahguna yang menjalani rehabilitasi rawat inap tidak dapat berinteraksi dengan penyalahguna yang tidak menjalani rehabilitasi.

5. Laju kematian karena narkotika diasumsikan 0 .

Dibawah ini merupakan diagram transfer model matematika penyebaran penyalahgunaan narkotika dengan memperhatikan tipe rehabilitasi: 


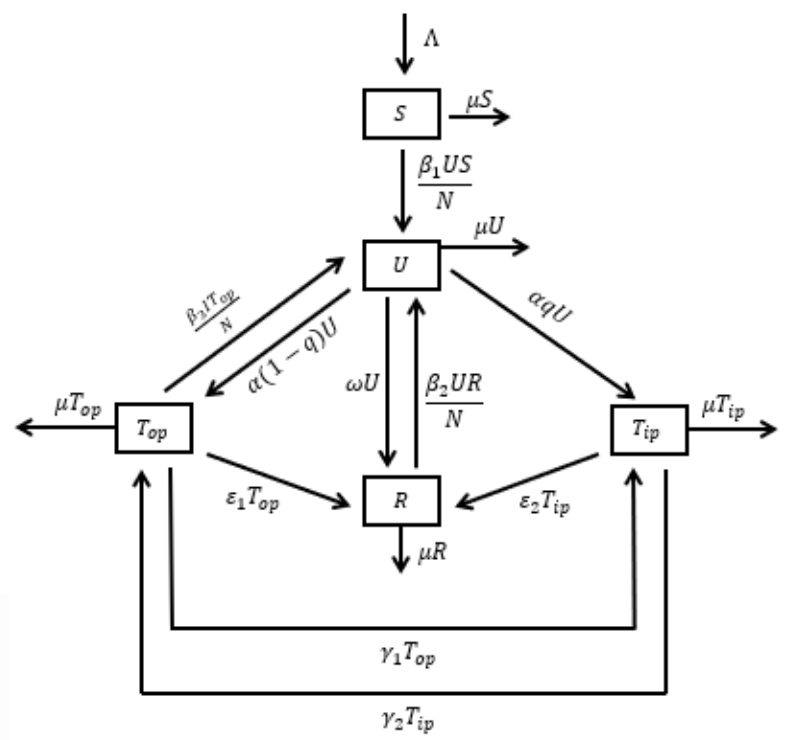

Gambar 1. Diagram transfer model matematika penyebaran penyalahgunaan narkotika dengan memperhatikan tipe rehabilitasi

Dengan keterangan parameter sebagai berikut:

$\Lambda \quad$ : Laju populasi umum memasuki populasi rentan

$\mu \quad$ : Laju kematian alami dari populasi umum

$\beta_{1} \quad$ : Probabilitas individu rentan menjadi penyalahguna narkotika

$\beta_{2} \quad$ : Probabilitas individu yang pulih dari penyalahgunaan narkotika menjadi penyalahguna narkotika kembali atau kambuh

$\beta_{3} \quad$ : Probabilitas penyalahguna narkotika yang menjalani rehabilitasi rawat jalan menjadi penyalahguna narkotika kembali

$q \quad$ : Proporsi penyalahguna narkotika menjalani rawat inap

$\gamma_{1} \quad$ : Laju perpindahan individu dari rehabilitasi rawat jalan ke rehabilitasi rawat inap

$\gamma_{2} \quad$ : Laju perpindahan individu dari rehabilitasi rawat inap ke rehabilitasi rawat jalan

$\alpha \quad$ : Laju penyalahguna narkotika menjadi pasien rehabilitasi

$\varepsilon_{1} \quad$ : Laju pemulihan penyalahguna narkotika yang mendapatkan rehabilitasi rawat jalan menjadi kelas pulih

$\varepsilon_{2} \quad$ : Laju pemulihan penyalahguna narkotika yang mendapatkan rehabilitasi rawat inap menjadi kelas pulih

$\omega \quad$ : Laju pemulihan alami

Dari Gambar 1 dapat dijelaskan tentang penyebaran penyalahgunaan narkotika sebagai berikut:

1. Laju individu yang rentan menjadi penyalahguna narkotika adalah jumlah individu dalam populasi yang memasuki populasi rentan, dikurangi hasil bagi antara peluang individu menjadi penyalahgunaan narkotika dengan total populasi manusia, dikurangi dengan laju kematian alami.

2. Laju individu penyalahguna narkotika adalah hasil bagi antara peluang individu menjadi penyalahgunaan narkotika dengan total populasi manusia, ditambah hasil bagi antara peluang individu penyalahguna narkotika dan individu yang telah pulih dari penyalahgunaan narkotika dengan total populasi manusia, ditambah hasil bagi antara peluang individu penyalahguna narkotika dan individu yang menjalani rehabilitasi rawat jalan dengan total populasi manusia, 
dikurangi dengan laju kematian alami, laju pemulihan alami, dan laju penyalahguna narkotika menjadi pasien rehabilitasi.

3. Laju individu penyalahguna narkotika yang mendapat rehabilitasi rawat jalan adalah laju perpindahan individu dari rehabilitasi rawat inap ke rehabilitasi jalan, dikurangi laju kematian, laju perpindahan individu dari rehabilitasi rawat jalan ke rawat inap, dan laju pemulihan penyalahguna narkotika yang mendapatkan rehabilitasi rawat jalan menjadi pulih, ditambah laju penyalahguna menjadi pasien rawat jalan, dikurangi hasil bagi antara peluang individu penyalahguna narkotika dan individu yang menjalani rehabilitasi rawat jalan dengan total populasi manusia.

4. Laju individu penyalahguna narkotika yang mendapat rehabilitasi rawat inap adalah laju perpindahan individu dari rehabilitasi rawat jalan ke rehabilitasi rawat inap, dikurangi laju kematian alami, Laju perpindahan individu dari rehabilitasi rawat inap ke rehabilitasi rawat jalan, laju pemulihan penyalahguna narkotika yang mendapatkan rehabilitasi rawat inap menjadi pulih, dikurangi dengan laju penyalahguna menjadi pasien rawat inap.

5. Laju individu yang pulih dari penyalahgunaan narkotika adalah laju pemulihan penyalahguna narkotika yang mendapatkan rehabilitasi rawat jalan menjadi pulih, ditambah laju pemulihan penyalahguna narkotika yang mendapatkan rehabilitasi rawat inap menjadi kelas pulih, ditambah laju pemulihan alami, dikurangi ditambah hasil bagi antara peluang individu penyalahguna narkotika dan individu yang telah pulih dari penyalahgunaan narkotika dengan total populasi manusia, serta dikurangi laju kematian alami dari populasi umum.

Sehingga, berdasarkan asumsi-asumsi serta visualisasi dalam Gambar 1 dapat dibentuk model matematika penyebaran penyalahgunaan narkotika dengan memperhatikan tipe rehabilitasi, sebagai berikut:

$$
\begin{aligned}
& \frac{d S}{d t}=\Lambda-\frac{\beta_{1} U S}{N}-\mu S \\
& \frac{d U}{d t}=\frac{\beta_{1} U S}{N}+\frac{\beta_{2} U R}{N}+\frac{\beta_{3} U T_{o p}}{N}-(\mu+\omega+\alpha) U \\
& \frac{d T_{o p}}{d t}=\gamma_{2} T_{i p}-\left(\mu+\gamma_{1}+\varepsilon_{1}\right) T_{o p}+\alpha(1-q) U-\frac{\beta_{3} U T_{o p}}{N} \\
& \frac{d T_{i p}}{d t}=\gamma_{1} T_{o p}-\left(\mu+\gamma_{2}+\varepsilon_{2}\right) T_{i p}+\alpha q U \\
& \frac{d R}{d t}=\varepsilon_{1} T_{o p}+\varepsilon_{2} T_{i p}+\omega U-\frac{\beta_{2} U R}{N}-\mu R
\end{aligned}
$$

dengan parameter $\Lambda, \mu, \delta, \beta_{1}, \beta_{2}, \beta_{3}, q, \gamma_{1}, \gamma_{2}, \alpha, \varepsilon_{1}, \varepsilon_{2}, \omega>0$.

\section{Transformasi Model}

Total populasi manusia penyalahguna narkotika dalam model matematika ini dinyatakan dengan $N=S+U+T_{o p}+T_{i p}+R$. Sehingga laju perubahan total populasi manusia dapat ditulis sebagai berikut:

$$
\frac{d N}{d t}=\frac{d S}{d t}+\frac{d U}{d t}+\frac{d T_{o p}}{d t}+\frac{d T_{i p}}{d t}+\frac{d R}{d t} .
$$

Setelah persamaan (1) sampai persamaan (5) disubstitusikan, diperoleh $\frac{d N}{d t}=\Lambda-\mu N$. Sehingga saat $t \leq 1500$ maka $N \rightarrow \frac{\Lambda}{\mu}$. Oleh karena itu, persamaan (1), (2), (3), (4), (5) diberikan oleh 


$$
\Omega=\left\{N \leq \frac{\Lambda}{\mu}\right\}
$$

untuk selanjutnya, variabel $N$ dapat didekati dengan $N=\frac{\Lambda}{\mu}$.

Dengan demikian, model pada persamaan (1), (2), (3), (4), (5) dapat dituliskan sebagai berikut:

$$
\begin{aligned}
\frac{d S}{d t} & =\Lambda-\frac{\mu \beta_{1} U S}{\Lambda}-\mu S \\
\frac{d U}{d t} & =\frac{\mu \beta_{1} U S}{\Lambda}+\frac{\mu \beta_{2} U R}{\Lambda}+\frac{\mu \beta_{3} U T_{o p}}{\Lambda}-(\mu+\omega+\alpha) U \\
\frac{d T_{o p}}{d t} & =\gamma_{2} T_{i p}-\left(\mu+\gamma_{1}+\varepsilon_{1}\right) T_{o p}+\alpha(1-q) U-\frac{\mu \beta_{3} U T_{o p}}{\Lambda} \\
\frac{d T_{i p}}{d t} & =\gamma_{1} T_{o p}-\left(\mu+\gamma_{2}+\varepsilon_{2}\right) T_{i p}+\alpha q U \\
\frac{d R}{d t} & =\varepsilon_{1} T_{o p}+\varepsilon_{2} T_{i p}+\omega U-\frac{\mu \beta_{2} U R}{\Lambda}-\mu R
\end{aligned}
$$

\section{Estimasi Parameter}

Berikut merupakan estimasi parameter serta nilai awal tertentu untuk model matematika dalam penelitian ini.

Tabel 1. Estimasi Parameter Model Matematika Penyalahgunaan Narkotika dengan Memperhatikan Tipe Rehabilitasi

\begin{tabular}{cccc}
\hline Parameter & Nilai & Sumber & Satuan \\
\hline$\Lambda$ & $1.986,768$ & Estimasi & Orang/tahun \\
$\beta_{1}$ & 0,014 & Estimasi & $1 /$ tahun \\
$\beta_{2}$ & 0,0055 & Estimasi & $1 /$ tahun \\
$\beta_{3}$ & 0,063 & {$[13]$} & $1 /$ tahun \\
$q$ & 0,0005 & {$[17]$} & $1 /$ tahun \\
$\gamma_{1}$ & 0,02961 & {$[17]$} & $1 /$ tahun \\
$\gamma_{2}$ & 0,003 & {$[17]$} & $1 /$ tahun \\
$\alpha$ & 0,02827 & {$[17]$} & $1 /$ tahun \\
$\varepsilon_{1}$ & 0,01 & {$[17]$} & $1 /$ tahun \\
$\varepsilon_{2}$ & 0,3142 & {$[17]$} & $1 /$ tahun \\
$\omega$ & 0,0082 & {$[13]$} & $1 /$ tahun \\
\hline
\end{tabular}




\section{Titik Kesetimbangan Model Matematika Penyebaran Penyalahguna Narkotika}

Berdasarkan analisis yang telah dilakukan, diperoleh dua titik kesetimbangan yaitu:

a. Titik kesetimbangan bebas narkotika

Titik kesetimbangan bebas narkotika adalah suatu kondisi ketika tidak terjadi penyebaran narkotika dalam populasi, dalam hal ini dimaksudkan bahwa tidak ada manusia yang menyalahgunakan narkotika. Dengan demikian dapat dinyatakan $U=0$. Misalkan titik kesetimbangan bebas napza dinyatakan dalam $E^{0}=\left(S^{0}, U^{0}, T_{o p}^{0}, T_{i p}^{0}, R^{0}\right)$. Dengan mensubstitusikan $U=0$ ke persamaan (7), (8), (9), (10), (11) diperoleh titik kesetimbangaan bebas narkotika sebagai berikut:

$$
E^{0}=\left(S^{0}, U^{0}, T_{o p}^{0}, T_{i p}^{0}, R^{0}\right)=\left(\frac{\Lambda}{\mu}, 0,0,0,0\right)
$$

b. Titik kesetimbangan adanya penyebaran narkotika

Titik kesetimbangan adanya penyebaran narkotika adalah suatu kondisi ketika terjadi penyalahgunaan narkotika. Kondisi ini terjadi ketika terdapat populasi manusia rentan menyalahgunakan narkotika, populasi penyalahguna narkotika, populasi penyalahguna narkotika yang direhabilitasi rawat jalan, populasi penyalahguna narkotika yang direhabilitasi rawat inap, dan juga populasi penyalahguna yang pulih atau dapat dinyatakan dengan $S \neq 0, U \neq 0, T_{o p} \neq 0, T_{i p} \neq$ $0, R \neq 0$. Berdasarkan perhitungan, diperoleh titik kesetimbangan narkotika sebagai berikut:

$$
E^{*}=\left(S^{*}, U^{*}, T_{o p}^{*}, T_{i p}^{*}, R^{*}\right)
$$

dengan

$$
\begin{aligned}
S^{*} & =\frac{\Lambda^{2}}{\mu \beta_{1} U^{*}+\Lambda \mu} \\
T_{o p}^{*} & =\frac{\Lambda \alpha U^{*}\left(\left(\mu+\varepsilon_{2}\right)(1-q)+\gamma_{2}\right)}{\left(\mu \beta_{3} U^{*}+\Lambda\left(\mu+\varepsilon_{1}\right)\right)\left(\mu+\gamma_{2}+\varepsilon_{2}\right)+\Lambda \gamma_{1}\left(\mu+\varepsilon_{2}\right)} \\
T_{i p}^{*} & =\frac{\alpha U^{*}\left[\gamma_{1} \Lambda+q\left(\mu \beta_{3} U^{*}+\Lambda\left(\mu+\varepsilon_{1}\right)\right]\right.}{\left(\mu \beta_{3} U^{*}+\Lambda\left(\mu+\varepsilon_{1}\right)\right)\left(\mu+\gamma_{2}+\varepsilon_{2}\right)+\Lambda \gamma_{1}\left(\mu+\varepsilon_{2}\right)} \\
R^{*} & =\frac{\Lambda\left(\left(\varepsilon_{1} T_{o p}^{*}+\omega U^{*}\right)\left(\mu+\gamma_{2}+\varepsilon_{2}\right)+\varepsilon_{2}\left(\gamma_{1} T_{o p}+\alpha q U^{*}\right)\right)}{\mu\left(\mu+\gamma_{2}+\varepsilon_{2}\right)\left(\beta_{2} U+\Lambda\right)}
\end{aligned}
$$

sedangkan $U^{*}$ merupakan akar dari polinomial berderajat dua seperti berikut:

$$
B_{1} I^{* 2}+B_{2} I^{*}+B_{3}=0
$$

dengan

$$
\begin{aligned}
B_{1}= & \Lambda^{2} \beta_{1} \beta_{2} \beta_{3} \mu^{2} \gamma_{1} n_{3}^{2}+\Lambda^{2} \alpha n_{1} n_{2} \beta_{1} \beta_{2} \mu+\Lambda \alpha n_{1} n_{3} \beta_{2} \beta_{3} \mu+\Lambda \beta_{2} \beta_{3} \omega n_{3}^{2} \mu+ \\
& \Lambda \beta_{2} \beta_{3} \varepsilon_{2} \alpha q n_{3} \mu \\
B_{2}= & \Lambda^{3} \beta_{1} \beta_{2} \mu n_{3}^{2} \varepsilon_{1}+\Lambda^{3} \beta_{1} \beta_{2} \mu^{2} \gamma_{1} n_{3}+\Lambda^{3} \beta_{1} \beta_{2} \mu n_{3} \gamma_{1} \varepsilon_{2}+\Lambda^{3} \beta_{1} \beta_{3} \mu^{2} n_{3}^{2}+ \\
& \Lambda^{3} \beta_{1} \beta_{2} \mu^{2} n_{3}^{2}+\Lambda^{3} \alpha n_{1} n_{2} \beta_{2} \mu+\Lambda^{2} \alpha n_{1} n_{3} \beta_{3} \mu+\Lambda^{2} \beta_{2} \omega n_{3}^{2} \mu+\Lambda^{2} \beta_{2} \omega n_{3}^{2} \varepsilon_{1}+ \\
& \Lambda^{2} \beta_{2} \omega n_{3} \gamma_{1} \mu+\Lambda^{2} \beta_{2} \omega n_{3} \gamma_{1} \varepsilon_{2}+\Lambda^{2} \beta_{2} \varepsilon_{2} \alpha q n_{3} \mu+\Lambda^{2} \beta_{2} \varepsilon_{1} \varepsilon_{2} \alpha q n_{3}+
\end{aligned}
$$




$$
\begin{aligned}
& \Lambda^{2} \beta_{2} \varepsilon_{2} \alpha q \gamma_{1} \mu+\Lambda^{2} \beta_{2} \varepsilon_{2}^{2} \alpha q \gamma_{1}+\Lambda^{2} \beta_{2} \mu n_{3}^{2}(\mu+\omega+\alpha)+\Lambda \beta_{2} \varepsilon_{1} n_{3}^{2}(\mu+\omega+ \\
& \alpha)+\Lambda^{2} \beta_{2} \gamma_{1} \mu n_{3}(\mu+\omega+\alpha)+\Lambda^{2} \beta_{2} \gamma_{1} \varepsilon_{2} n_{3}(\mu+\omega+\alpha)+\Lambda^{2} \beta_{3} n_{3} \mu(\mu+\omega+ \\
& \alpha) \\
B_{3}= & \Lambda^{4} \beta_{1} \mu^{2} n_{3}^{2}+\Lambda^{4} \beta_{1} \mu n_{3}^{2} \varepsilon_{1}+\Lambda^{4} \beta_{1} \mu^{2} \gamma_{1} n_{3}+\Lambda^{4} \beta_{1} \mu n_{3} \gamma_{1} \varepsilon_{2}+\Lambda^{3} \gamma_{1} \mu n_{3}(\mu+\omega+ \\
& \alpha)+\Lambda^{3} \mu n_{3}^{2}(\mu+\omega+\alpha)+\Lambda^{2} \varepsilon_{1} n_{3}^{2}(\mu+\omega+\alpha)+\Lambda^{3} n_{3} \gamma_{1} \varepsilon_{2}(\mu+\omega+\alpha)
\end{aligned}
$$

\section{Bilangan Reproduksi Dasar}

Bilangan reproduksi dasar $\left(R_{0}\right)$ merupakan bilangan yang menyatakan jumlah rata-rata banyaknya individu rentan yang terinfeksi secara langsung oleh individu terinfeksi dalam populasi individu rentan [18]. Jika $R_{0}<1$ maka populasi akan bebas dari penyebaran narkotika, sedang jika $R_{0}>1$ maka penyebaran akan terus terjadi atau mengakibatkan adanya penyebaran penyalahgunaan narkotika pada populasi tersebut [19].

Metode yang akan digunakan untuk menentukan $R_{0}$ pada penelitian ini adalah metode Next Generation Matrix (NGM) berdasarkan langkah-langkah pada [18]. Untuk mendapatkan $R_{0}$ terdapat tiga kelas yang menjadi penyebab penyalahgunaan narkotika, yaitu $U, T_{o p}$, dan $T_{i p}$. Jika $x=$ $\left(U T_{o p} T_{i p}\right)$, maka persamaan (9), (10), (11) pada model dapat ditulis sebagai $\frac{d x}{d t}=F(x)-Z(x)$, dengan

$$
F(x)=\left(\frac{\frac{\mu \beta_{1} U S}{\Lambda}+\frac{\mu \beta_{2} U R}{\Lambda}+\frac{\mu \beta_{3} U T_{o p}}{\Lambda}}{-\frac{\mu \beta_{3} U T_{o p}}{\Lambda} 0}\right),
$$

dan

$$
Z(x)=\left(\frac{(\mu+\omega+\alpha) U}{-\gamma_{2} T_{i p}+\left(\mu+\gamma_{1}+\varepsilon_{1}\right) T_{o p}-\alpha(1-q) U-\gamma_{1} T_{o p}+\left(\mu+\gamma_{2}+\varepsilon_{2}\right) T_{i p}-\alpha q U}\right) .
$$

Misalkan $F$ dan $Z$ berturut-turut merupakan matriks Jacobian dari matriks $F(x)$ dan $Z(x)$. Selanjutnya mensubstitusikan titik setimbang bebas narkotika $E_{0}=\left(\frac{\Lambda}{\mu}, 0,0,0,0\right)$ ke dalam matriks tersebut didapatkan $F$ dan $Z$ sebagai berikut:

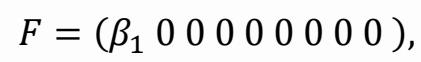

dan

$$
Z=\left((\mu+\omega+\alpha) 00-\alpha(1-q)\left(\mu+\gamma_{1}+\varepsilon_{1}\right)-\gamma_{2}-\alpha q-\gamma_{1}\left(\mu+\gamma_{2}+\varepsilon_{2}\right)\right)
$$

Pada metode Next Generation Matrix, $R_{0}$ diperoleh dari nilai eigen terbesar dari matriks $F Z^{-1}$, sehingga diperoleh bilangan reproduksi dasar sebagai berikut:

$$
R_{0}=\frac{\beta_{1}}{\mu+\omega+\alpha} .
$$

Jika semua parameter disubstitusikan pada $R_{0}$ maka $R_{0}=0,1089756291<1$. Berdasarkan [19] maka penyalahgunaan narkotika mempunyai kestabilan titik kesetimbangan bebas narkotika. 


\section{Analisis Kestabilan Titik Setimbang}

Model matematika penyalahgunaan narkotika memperhatikan tipe rehabilitasi berbentuk sistem persamaan diferensial non linier, oleh sebab itu untuk menganalisis kestabilan titik setimbangnya cukup sukar. Sehingga, diperlukan linierisasi dengan menggunakan matriks Jacobian seperti pada [20].

Matriks Jacobian dari model matematika pada penelitian ini adalah sebagai berikut:

$$
\begin{gathered}
J=\left(-\frac{\mu \beta_{1} U}{\Lambda}-\mu \frac{\mu \beta_{1} U}{\Lambda} 0000-\frac{\mu \beta_{1} S}{\Lambda} \frac{\mu \beta_{1} S}{\Lambda}+\frac{\mu \beta_{2} R}{\Lambda}+\frac{\mu \beta_{3} T_{o p}}{\Lambda}-d_{1} \alpha(1-q) \alpha q \omega-\frac{\mu \beta_{2} R}{\Lambda} 0 \frac{\mu \beta_{3} U}{\Lambda}-\right. \\
\left.\frac{\mu \beta_{3} U}{\Lambda}-d_{2} \gamma_{1} \varepsilon_{1} 00 \gamma_{2}-d_{3} \varepsilon_{2} 0 \frac{\mu \beta_{2} U}{\Lambda} 00-\frac{\mu \beta_{2} U}{\Lambda}-\mu\right)
\end{gathered}
$$

dengan

$$
\begin{aligned}
& d_{1}=\mu+\omega+\alpha \\
& d_{2}=\mu+\gamma_{1}+\varepsilon_{1} \\
& d_{3}=\mu+\gamma_{2}+\varepsilon_{2} .
\end{aligned}
$$

\section{Analisis Kestabilan Titik Setimbang Bebas Narkotika}

Analisis kestabilan pada titik setimbang bebas narkotika dimulai dari mensubstitusi nilai titik setimbang bebas narkotika yaitu $E_{0}=\left(\frac{\Lambda}{\mu}, 0,0,0,0\right)$ ke matriks Jacobian, sehingga diperoleh

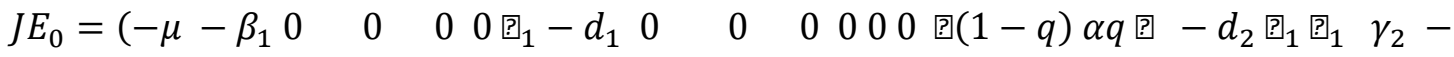

$$
\begin{aligned}
& \left.d_{3} \text { ? }_{2} \quad 00-\mu\right)
\end{aligned}
$$

Selanjutnya matriks Jacobian $J E_{0}$ diatas dibentuk ke dalam persamaan karakteristik untuk mencari nilai eigen dengan menggunakan $\operatorname{det} \operatorname{det}\left(J E_{0}-\lambda I\right)=0$ yang mana didapatkan hasil sebagai berikut:

$-\left(-\beta_{1}+d_{1}+\lambda\right)(\mu+\lambda)\left(\lambda^{3}+\left(d_{2}+d_{3}+\mu\right) \lambda^{2}+\left(d_{2} d_{3}+d_{2} \mu+d_{3} \mu-\gamma_{1} \gamma_{2}\right) \lambda-\gamma_{1} \gamma_{2} \mu+\right.$ $\left.d_{2} d_{3} \mu\right)=0$

atau didapatkan bentuk ekuivalen seperti berikut ini:

$$
-(\lambda+\mu)\left(-\beta_{1}+d_{1}+\lambda\right)\left(\lambda^{3}+a_{0} \lambda^{2}+a_{1} \lambda+a_{2}\right)=0
$$

Dari persamaan karakteristik tersebut, diperoleh nilai eigen $\lambda_{1}=-\mu$ dan $\lambda_{2}=\beta_{1}-(\mu+\omega+\alpha)$. Dengan substitusi parameter didapat bahwa $\lambda_{1}=-0,014$ dan $\lambda_{2}=-0,04497$. Dapat dilihat bahwa $\lambda_{1}, \lambda_{2}<0$ karena semua parameter bernilai positif. Sisanya adalah persamaan karakteristik

dimana

$$
\lambda^{3}+a_{0} \lambda^{2}+a_{1} \lambda+a_{2}=0
$$

$a_{0}=d_{2}+d_{3}+\mu$

$a_{1}=d_{2} d_{3}+d_{2} \mu+d_{3} \mu-\gamma_{1} \gamma_{2}$

$a_{2}=-\gamma_{1} \gamma_{2} \mu+d_{2} d_{3} \mu$.

Berdasarkan kriteria Routh-Hurwitz dalam [21], nilai eigen $\lambda_{3}, \lambda_{4}$, dan $\lambda_{5}$ akan bernilai negatif jika $a_{0}>0, a_{1}>0, a_{2}>0$, dan $a_{0} a_{1}-a_{2}>0$. Dengan mensubstitusi parameter diperoleh nilai $a_{0}=$ $0.39881>0, a_{1}=0.023054142>0, a_{2}=0.000247335228>0$, dan $a_{0} a_{1}-a_{2}=0.00895>0$. Sehingga terbukti bahwa $\lambda_{3}, \lambda_{4}$, dan $\lambda_{5}$ bernilai negatif. Oleh karena itu, titik setimbang bebas narkotika $E^{0}=\left(S^{0}, U^{0}, T_{o p}^{0}, T_{i p}^{0}, R^{0}\right)$ stabil asimtotik. 


\section{Simulasi Numerik Analisa Kestabilan}

Dengan estimasi parameter di atas diperoleh $R_{0}=0,1089756291<1$. Pada kondisi ini, sistem akan stabil asimtotik menuju titik kesetimbangan $E^{0}=\left(S^{0}, U^{0}, T_{o p}^{0}, T_{i p}^{0}, R^{0}\right)=$ (141.912; $0 ; 0 ; 0 ; 0)$, artinya pada kondisi yang cukup lama $(t \rightarrow \infty)$ proporsi individu pada masingmasing kelas akan menuju titik ekuilibrium bebas narkotika. Proporsi kelas populasi individu rentan menyalahgunakan narkotika akan menuju 141.912, proporsi untuk kelas individu yang lainnya akan menuju 0 , dengan kata lain tidak ada populasi individu yang menjadi penyalahguna narkotika, tidak ada populasi individu yang direhabilitasi rawat jalan maupun inap. Hal ini menunjukkan bahwa pada saat $R_{0}<1$, pada waktu tertentu proporsi individu akan menuju titik kesetimbangan dengan ratarata penyalahgunaan narkotika tidak menyebar dalam populasi.

Jika diberikan nilai awal yaitu $S(0)=135.305, U(0)=743, T_{o p}(0)=3.584, T_{i p}(0)=$ $780, R(0)=1.500$, maka menggunakan bantuan Maple 2020 grafik simulasi disajikan pada Gambar 2 berikut:

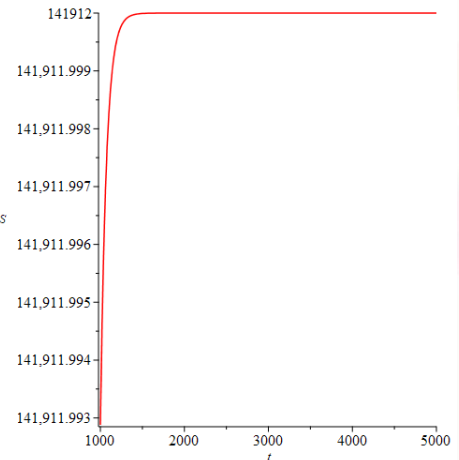

(a)

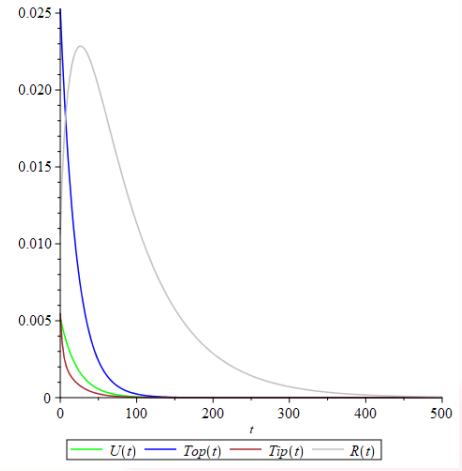

(b)

Gambar 2(a). Plot populasi rentan, 2(b). Plot populasi penyalahguna narkotika, penyalahguna yang mendapat rehabilitasi rawat jalan, penyalahguna yang mendapat rehabilitasi rawat inap, pulih dari penyalahgunaan narkotika

Gambar 2(a) menunjukkan bahwa grafik kelas individu rentan (Susceptible) terhadap waktu $t$ mengalami kenaikan pada populasi nilai awal yang telah ditentukan sebesar 135.305 menuju 141.912. Kenaikan tersebut diakibatkan oleh laju populasi umum yang memasuki populasi rentan setiap tahunnya. Grafik di atas stabil karena menuju titik kesetimbangan yaitu $S^{0}=141.912$.

Gambar 2(b) menunjukkan bahwa kelas populasi individu penyalahguna (users) terhadap waktu $t$ mengalami penurunan akibat adanya kematian alami, pemulihan alami, serta penyalahguna yang kemudian direhabilitasi. Sementara kelas populasi individu penyalahguna yang direhabilitasi rawat jalan (outpatient) terhadap waktu $t$ mengalami penurunan akibat adanya kematian alami, perpindahan penyalahguna narkotika yang direhabilitasi rawat jalan menjadi rehabilitasi rawat inap, perpindahan penyalahguna narkotika yang direhabilitasi rawat jalan menjadi pulih, serta dikarenakan adanya interaksi dengan penyalahguna yang tidak direhabilitasi sehingga dapat beresiko menjadi penyalahguna narkotika kembali. Sedangkan kelas populasi individu penyalahguna yang direhabilitasi rawat inap (inpatient) terhadap waktu $t$ mengalami penurunan populasi nilai awal yang akibat adanya kematian alami, perpindahan penyalahguna narkotika yang direhabilitasi rawat inap menjadi rehabilitasi rawat jalan, dan perpindahan penyalahguna narkotika yang direhabilitasi rawat inap menjadi pulih. Selanjutnya kelas populasi individu penyalahguna narkotika yang pulih mengalami kenaikan akibat penyalahguna yang mendapat rehabilitasi maupun tidak telah pulih dari penyalahgunaan narkotika. Akan tetapi setelah itu, individu yang pulih mengalami penurunan akibat 
tidak adanya penambahan dari kelas penyalahguna narkotika serta adanya kematian alami dari individu kelas ini. Grafik dikatakan stabil karena menuju titik ekuilibrium $\left(U^{0}, T_{o p}^{0}, T_{i p}^{0}, R^{0}\right)=0$, artinya penyebaran penyalahgunaan dalam waktu tertentu semakin berkurang dan berangsur-angsur hilang dalam populasi.

\section{Kesimpulan}

Model matematika pada penyebaran penyalahgunaan narkotika ini memiliki titik ekuilibrium bebas penyakit stabil asimtotik lokal dengan nilai $R_{0}=0,1089756291<1$ yaitu $E^{0}=$ $\left(S^{0}, U^{0}, T_{o p}^{0}, T_{i p}^{0}, R^{0}\right)=(141.912 ; 0 ; 0 ; 0 ; 0)$, artinya pada masing-masing kelas akan menuju titik ekuilibrium bebas narkotika yang mana jumlah penyalahguna narkotika akan berkurang dan dalam jangka waktu tertentu sudah tidak menyebar. Jika pada suatu saat tertentu jumlah penyalahguna narkotika justru bertambah, cara yang dapat dilakukan yaitu dengan mengurangi interaksi individu penyalahguna narkotika dengan individu rentan menyalahgunakan narkotika serta meningkatkan kesadaran seseorang dari penyalahgunaan narkotika dengan memberikan penyuluhan dampak negatif narkotika bagi kesehatan.

Hasil simulasi menggunakan data penyebaran penyalahgunaan narkotika di Indonesia tahun 2020 menunjukkan bahwa penyebaran narkotika tidak lagi menjadi endemi dengan nilai $R_{0}<1$. Hal ini dipengaruhi oleh adanya program rehabilitasi sebagai bentuk hukuman dan upaya perawatan yang diharapkan kecenderungan seseorang yang sudah pulih menyalahgunakan narkotika untuk menyalahgunakan kembali dapat hilang dan tidak akan menyalahgunakan kembali.

\section{Referensi}

[1] F. Pasaribu, "Tinjauan Etika Kristen Terhadap Korban Napza”, AgriXiv, preprint, Mar. 2020. doi: 10.31220/osf.io/rhfx4

[2] E. Yuliza, M. Rosha, and R. Sriningsih, "Model Matematika Jumlah Pemakai Narkoba dengan Program Rehabilitasi", UNP J. Math., vol. 1 no. 1, p. 6, 2014

[3] Republik Indonesia, "Undang-Undang No. 2 Tahun 1997 tentang Narkotika", Lembaran Negara RI Tahun 1997, No. 67. Menteri Negara Sekretaris Negara, Jakarta, 1997

[4] Resmawan, "Model Matematika SURS Pada Penyebaran Pengguna Narkoba", Penerbit HKI Kemenkumham RI, 2020, [Online]. Available: https://repository.ung.ac.id/karyailmiah/show/4533/model-matematika-surs-pada penyebaran-pengguna-narkoba.html

[5] Y. Apandi, "Katakan tidak pada narkoba, Cet. 1", Bandung: Simbiosa Rekatama Media, 2010

[6] A. Ikbal, "Model Matematika Pertumbuhan Populasi Pecandu Narkoba dengan Program Rehabilitasi di Kota Bandung", Universitas Pendidikan Indonesia, 2019

[7] P. Simanungkalit, "Globalisasi peredaran narkoba dan penanggulangannya di Indonesia, Cet. 2", Jakarta: Yayasan Wajar Hidup : Didistribusikan oleh Yayasan Wajar Hidup dan DPN GEPENTA, 2011

[8] Widowati dan Sutimin, "Buku Ajar Pemodelan Matematika", Semarang: Universitas Diponegoro, 2007

[9] Rohaeti, E dan A. Andriyati, "Pengembangan Model Matematika Dinamika Perokok di Kota Bogor", KUBIK: Jurnal Publikasi Ilmiah Matematika Vol. 4 No. 1, pp. 131-139, 2019

[10] Aryani, I dan R. Rahmi, " Analisis dan Simulasi Model Matematika untuk Kehidupan Sosial dan Dominasi dalam Koloni Semut Leptothorax Acervorum", KUBIK: Jurnal Publikasi Ilmiah Matematika Vol. 3 No. 2, pp.117-122, 2018

[11] E. White and C. Comiskey, "Heroin epidemics, treatment and ODE modelling", Math. Biosci., Vol. 208, No. 1, pp. 312-324, 2007 
[12] M. R. Husain.,dkk, "Analisis Kestabilan Model Penyebaran Pengguna Narkoba dengan Faktor Edukasi", Barekeng J. Ilmu Mat. Dan Terap., Vol. 14 No. 1, pp. 069-078, 2020

[13] J. Mushanyu and F. Nyabadza, "A Risk-Structured Model for Understanding the Spread of Drug Abuse", Int. J. Appl. Comput. Math., Vol. 4 No. 2, p. 60, 2018

[14] M. Ma, et al, "Dynamics of synthetic drugs transmission model with psychological addicts and general incidence rate", Phys. Stat. Mech. Its Appl., Vol. 491, pp. 641-649, 2018

[15] J. Mushanyu, et al, "Modelling Drug Abuse Epidemics in the Presence of Limited Rehabilitation Capacity," Bull. Math. Biol., vol. 78 no. 12, pp. 2364-2389, 2016

[16] R. Sriningsih, "Pengaruh Hukuman Mati terhadap Dinamika Jumlah Pengguna Narkoba di Indonesia," no. 2, p. 8, 2015

[17] J. Mushanyu, "Role of imitation and limited rehabilitation capacity on the spread of drug abuse," BMC Res. Notes, vol. 11, no. 1, p. 493, 2018

[18] P. van den Driessche and J. Watmough, "Reproduction numbers and sub-threshold endemic equilibria for compartmental models of disease transmission," Math. Biosci., vol. 180, no. 1-2, pp. 29-48, 2002

[19] F. Brauer and C. Castillo-Chavez, "Mathematical Models in Population Biology and Epidemiology, " vol. 40. New York, NY: Springer New York, 2012. doi: 10.1007/978-1-4614-16869

[20] D. G. Zill and M. R. Cullen, "Differential equations with boundary-value problems," 7th ed. Belmont, CA: Brooks/Cole, Cengage Learning, 2009

[21] D. R. Merkin, "Introduction to the theory of stability," Penerbit Springer, New York, 1997 